Jan Amcoff

\title{
Socialbidragstagares flytt mellan storstad och avfolkningsbygd
} Social dumpning eller problemanhopning i förorten?

\begin{abstract}
Migration of social beneficiaries between ton and country: Social dumping or accumulation of problems in the suburbs?

The patterns of internal migration in Sweden among people on social benefits have been much debated in newspapers and in other general debates around the year 2020, but the knowledge base in this field is limited. Based on register data, this study concludes that people supported by social benefits are more prone to move, although their deviation from the general pattern is decreasing; that the net redistribution brings social beneficiaries from municipalities with decreasing populations to the big cities rather than the other way around, and certainly so among people of foreign background; that long-term social beneficiaries who move in the other direction have an increased likelihood to move on; and that the net pattern remains also when the effects of other attributes on migration are controlled for in a regression model. Thus, the migration patterns among long-term social beneficiaries hint mainly at a "social import" to the big cities from municipalities with decreasing populations, rather than the opposite.
\end{abstract}

Jan Amcoffär docent vid Kulturgeografiska institutionen, Uppsala universitet.

Kontakt: jan.amcoff@kultgeog.uu.se 


\section{Inledning}

Under de senaste åren har dagspressen ägnat mycket spaltutrymme åt skriverier om hur biståndsbehövande flyttar till småkommuner med befolkningsminskning och lediga bostäder. Det gäller i synnerhet tidningar som täcker de delar av landet som uppfattar sig utsatta för fenomenet i fråga, men också rikspressen har uppmärksammat saken. Det finns prov på såväl nyhetsartiklar (se t.ex. Gustafsson 2020; Borglin 2019; Knutson 2019), som ledarkommentarer (t.ex. Höen Bustos 2020; Wallin 2019; Sjöstedt 2019) och debattartiklar/krönikor (t.ex. Ekorre 2020; Johansson 2019; Swedin 2019). Kommuner har, enligt uppgifter, stämt varandra (t.ex. Fritze 2015; Johansson 2017), och frågan debatterades i riksdagen (Dahlqvist 2019; Oscarsson 2021).

I skriverierna kan två huvudsakliga vinklar urskiljas. Ibland görs gällande att storstadskommuner på olika sätt har satt i system att "dumpa" biståndsbehövande i kommuner utan bostadsbrist, något som de anklagade kommunerna emellertid förnekar. Andra gånger riktar framställningarna snarare in sig på fastighetsägare som köper upp vad som brukar beskrivas som hälsovådliga och fallfärdiga flerbostadshus i bruksorter, för att hyra ut till dem som inte lyckats få någon lägenhet på storstädernas hårda bostadsmarknader. Det ena utesluter naturligtvis inte det andra och ibland sammanförs de två perspektiven. I kölvattnet av medieuppmärksamheten genomförde Tidningarnas Telegrambyrå en enkätundersökning riktad till samtliga kommuners socialtjänster. Av 159 svarande socialtjänster uppgav 71 procent att de upplever sig drabbade av dumpningsbeteenden (Eriksson 2020). Regeringen (2020) har reagerat genom att uppdra till Statskontoret "att kartlägga aktiv medverkan till bosättning i annan kommun".

Resultatet av Statskontorets (2020) kartläggning presenterades senhösten 2020. En enkätdel bekräftar TT:s slutsats att majoriteten av kommunerna upplever sig utsatta för "social dumpning", att det i synnerhet gäller kommuner med låg skattekraft, och visade därtill bland annat att nästan var fjärde svarande kommun villkorar socialbidrag med att mottagaren söker boende utanför kommunen. Kritiker avfärdar emellertid det sistnämnda som en vantolkning (Delby 2020). Statskontoret analyserar också intervjurundor och annat sekundärmaterial innan de når slutsatsen att den företeelse de haft i uppdrag att kartlägga är "svårfångad" (s. 52), men föreslår ändå insatser för att dels öka det mellankommunala samarbetet, dels tydliggöra regelverk av relevans för frågan. I kölvattnet av Statskontorets kartläggning har debatten gått vidare i såväl pressen (t.ex. Löfstrand 2021 eller Gard \& Lundgren 2021) som i riksdagen (Oscarsson 2021).

Samtidigt som, företrädesvis landsortspress, skriver om denna så kallade "sociala export" från de mest tätbefolkade och välbeställda delarna av landet till småkommuner med befolkningsminskning, hörs också en annan diskussion. De uppfattade 
problemen består då av att det i en del storstadskommuner finns bostadsområden som alltmer har kommit att präglas av trångboddhet och sociala problem, men trots detta drar till sig än fler inflyttande i utsatta socioekonomiska situationer. På ett mer allmänt plan efterlyses härvidlag ett delat ansvar mellan landets kommuner (se t.ex. Godner 2018). Explicit har mycket fokus i den debatten legat på att få till stånd justeringar av den så kallade EBO-lagen (som i själva verket inte är en lag, utan en paragraf i lagen om mottagande av asylsökande, SFS 1994:137), trots att nämnda flyttning förstås inte är begränsad till denna grupp. EBO står för "eget boende" och innebär att asylsökande kan tacka nej till Migrationsverkets logi till förmån för en egen lösning (hos exempelvis släkt eller vänner), en möjlighet som majoriteten av dem nyttjade i slutet av 2010-talet. Politiker från Södertälje och Malmö kommuner har drivit EBO-frågan hårt och därmed fått symbolisera den (se t.ex. Godner 2016 och Stjernfeldt-Jammeh 2018). Deras politiska arbete har till sist burit frukt och den 1 januari 2020 ändrades lagen. Asylsökande som bosätter sig i områden med "sociala och ekonomiska utmaningar" (SFS 2019:1204) får numera undantas från rätten till bistånd.

Många kommuner anser sig alltså - på olika grunder - ha fått för stor börda av bidragstagare mot slutet av 2010-talet. I pressklippen antyds ibland att intensifieringen i uppmärksamhet skulle kunna kopplas samman med att kommunernas bostadsåtaganden gentemot dem som blivit kvar i Sverige, av dem som kom hit med 2015 års stora våg av asylsökande, har börjat löpa ut (t.ex. Eriksson 2020). Fast detta slags mellankommunala dispyter är inte nya. Möjligen går de ända tillbaka till 1700- och 1800-talens så kallade sockenkrig, när landets socknar regelmässigt försökte hindra inflyttning av fattigvårdsberättigade (se t.ex. Olausson 2016). Definitivt kan de följas i pressinlägg, åtminstone tillbaka till 1990-talet. Redan då anklagades till exempel "mindre nogräknade fastighetsägare" i nordvästra Skåne för att fylla dyra och svåruthyrda lägenheter med inflyttande socialbidragstagare (Helsingborgs Dagblad 1998). En artikel om kommuners "bollande" med socialt utsatta illustrerades med en behövande familj från "Stockholmstrakten" som hamnar i "den lilla Smålandskommunen" (Olsson 1999). Samtidigt tyckte sig också en del Stockholmskommuner på samma vis vara förfördelade (t.ex. Björkqvist 1996).

Pressklippen och samhällsdebatten har mest handlat om det som antas ligga bakom bidragstagarnas flyttningar, och som någon part skulle vilja förändra. Till de vanligaste kandidaterna hör alltså kommunala dumpningsbeteenden, "oseriösa" hyresvärdar och EBO-lagen. Den underliggande faktorn - hur själva omflyttningen bland människor som uppbär försörjningsstöd (socialbidrag) ser ut - har rönt mindre uppmärksamhet. Syftet med den här studien är därför att belysa just hur denna grupps flyttning ser ut, jämfört med de generella flyttmönstren. Givet mediebilden kommer fokus att ligga på flyttutbytet mellan storstadskommuner och kommu- 
ner med befolkningsminskning. Mer specifikt undersöks om socialbidragstagare är mer eller mindre flyttningsbenägna än andra, i vilken utsträckning deras flyttlass går från storstad till avfolkningsbygd och vice versa, hur dessa flyttmönster har utvecklats över tid under se senaste decennierna och hur permanenta socialbidragstagarnas flyttningar är.

\section{Litteraturöversikt}

Social export kan på ett principiellt plan förstås som att vissa kommuner drar ned på sina välfärdsåtaganden för att kunna göra sig av med bidragstagare. De "oseriösa" hyresvärdar som utpekas i debatten antas dra nytta av den situation som då uppstår. Geografiska välfärdsvariationers betydelse för välfärdsberättigades flyttningar har tidigare studerats under rubriken "välfärdsmagneter", huvudsakligen inom den nationalekonomiska disciplinen.

En stor del av studierna inom det här området är utförda i USA, ofta i anslutning till någon särskild typ av geografiskt varierande stöd, som Aid to families with dependent children (t.ex. McKinnish 2005), eller sjukvårdsförsäkringsprogrammet Medicaid (t.ex. Schwarz \& Sommers 2014). Från att för några decennier sedan ha varit baserade på aggregerade data och så grovhuggna geografiska enheter som delstater (t.ex. Gramlich \& Laren 1984), har mer detaljerade data på högre geografiska upplösningsnivåer inneburit ökade möjligheter att försäkra sig om att resultaten inte störs av andra faktorer än de som undersöks. De nyare studierna visar på begränsade (t.ex. Alm \& Enami 2017; Boffy-Ramirez 2013) eller inga (t.ex. Schwarz \& Sommers 2014; Goodman 2017) effekter av välfärdssystemens generositet på de välfärdsberättigades flyttningar.

I Europa har De Giorgi och Pellizzari (2009) funnit stöd för att invandrare välfärdsflyttar mellan EU:s medlemsstater, men att effekten är liten. Inom EU-länder finns studier som har visat att ett geografiskt begränsat stödprogram i Spanien hade vissa effekter på såväl flyttmönster som kvarboendegrad (Jofre-Monseny 2014) och att kommunernas varierande generositet med bidrag i Norge hade effekter på bidragstagarnas flyttmönster (Fiva 2009). I Sverige har Edmark (2007; 2009) undersökt om, mellan stadsdelar i Stockholm, varierande kravskärpningar på socialbidragstagare påverkade deras bosättningsmönster. Hon fann att så inte var fallet.

I många länder är socialbidrag och andra typer av välfärdsförmåner nationella angelägenheter. Då finns inga formella geografiska skillnader i generositet och heller inget lokalt eller regionalt betalningsansvar. Följaktligen blir frågan om välfärdsmagnetism mindre aktuell, men har ibland ändå undersökts. I till exempel Storbritannien har inflyttningen av socialt utsatta ibland uppmärksammats i studier av changerade badorter. Föreslagna förklaringar hänvisar till förekomst av billiga bostäder (ofta före 
detta semesterbostäder med delade kök och badrum) och hyresvärdar som accepterar att hyran betalas med bidrag (t.ex. Beatty \& Fothergill 2004; Ward 2015).

Sammanfattningsvis är litteraturen om välfärdsmagneter primärt inte intresserad av socialbidragstagare, utan snarare av välfärdsförmåner i allmänhet. Vidare har studier av välfärdsmagneter gett olika resultat, men med ju bättre data som har analyserats och ju mer sofistikerade metoder som använts, desto svagare förefaller det empiriska stödet för tanken om välfärdsmagneter ha blivit.

Bostadsmarknaden är också central i debatten eftersom den sociala exporten antas utlösas när de exporterande kommunerna "hjälper" sina bidragstagare att hitta bostad (i någon annan kommun) och det är bostäder som de "oseriösa" fastighetsägarna antas locka sina bidragstagande hyresgäster med. Det aktualiserar här en andra litteratur, som fokuserar Sveriges förändrade bostadsmarknad, i synnerhet hur allmännyttans roll har förändrats. Westerdahl (2020) ger en generell bild av förändringsprocesser på bostadsmarknaden. Grander $(2017$; 2018) menar att allmännyttiga bostadsbolag numera, retoriken till trots, exkluderar vissa grupper, men att deras tillämpning av bostadsmarknadens förändrade regelverk också varierar. Exempelvis godtar de ofta inte längre socialbidrag som hyreskontraktsberättigande inkomst, särskilt i större städer, i kommuner med "het" bostadsmarknad och i kommuner med borgerligt styre. De renoveringar och standarduppgraderingar som många bostadsområden genomgår, med hyreshöjningar som följd, har också begripliggjorts som ett uttryck för att vinst-maximerande strävanden hos fastighetsägare har fått ökat spelrum (t.ex. Baeten et al. 2017). Såväl skärpta krav på hyresgäster som hyreshöjningar kan leda till motvilliga flyttbeslut. De drabbades traumatiska upplevelser och reaktioner (ibland organiserade motstånd), har också undersökts (t.ex. Polanska \& Richard 2018).

Å andra sidan finns också exempel på studier som ifrågasätter hur omfattande problemet är. Femenías et al. (2019) redovisar till exempel preliminära resultat som tyder på att de allra flesta som flyttar i samband med renoveringar har andra skäl. Hur det än är med det kan man konstatera att bostadsmarknaden i Sverige har förändrats på ett sätt som ger ökad grogrund för social dumpning. Fast inom denna litteratur förefaller undersökningarnas geografiska fokus ofta vara bostadsområdet, snarare än kommunen. Baeten och Listerborns (2015) artikel om Landskrona kommun utgör ett undantag. Det kan också noteras att inte heller de här studierna egentligen begränsar sig till, eller ens har fokus på, just socialbidragstagare.

Samhällsdebatterna till trots är socialbidrag ingen vanligt förekommande variabel i studier av mellankommunal flyttning. De flesta studier använder andra indikatorer med syfte att fånga socioekonomiska skillnader i flyttbenägenheterna, till exempel disponibel inkomst eller arbetslöshet. Till undantagen hör Åslund (2005) som, $i$ en studie av invandrares flyttmönster visar att dessa invånare tenderar att hamna i kommuner som bland annat kännetecknas av många biståndstagare. Det stämmer 
väl överens med ovan refererade debatt om EBO-lagens konsekvenser. Åslund diskuterar flera möjliga tolkningar av sitt resultat, om det reflekterar begränsade valmöjligheter, en spridd önskan att ha grannar i samma socioekonomiska situation som man själv befinner sig i, eller om det - $\mathrm{i}$ likhet med tanken om välfärdsmagneter - är så att invandrare söker sig till kommuner som härvidlag är generösare än andra. Amcoff, Niedomysl och Östh (2011a; 2011b) visar att förekomst av socialbidrag minskar benägenheten till flytt mellan kommunerna i Stockholms län bland invandrare, men ökar benägenheten till mer långväga flytt bland såväl invandrare som äldre.

Även inom ramen för segregationsforskning förekommer studier som beaktar attributet socialbidragstagare. Fast inte heller här spelar det första fiolen, och även den litteraturen intresserar sig för befolkningsomfördelning mellan bostadsområden inom en och samma kommun, snarare än mellan kommuner. Till exempel visar Andersson och Bråmå (2004) hur selektiv flyttning medverkar till att utsatta bostadsområden reproduceras. "Socialbidragstagare" är ett attribut som ökar sannolikheten att någon flyttar till, och minskar sannolikheten att flytta från, ett sådant område. I Bråmå och Andersson (2010) sätts särskilt fokus på betydelsen av utflyttningen ur sådana bostadsområden. Hedman, van Ham och Manley (2011) kommer fram till att hushåll som flyttar, generellt sett, tenderar att hamna i områden som präglas av hushåll snarlika dem själva. Till exempel tenderar socialbidragstagare att hamna tillsammans för sig i områden som andra hushållstyper undviker.

Av litteraturgenomgången framgår att det finns flera litteraturer som, utifrån olika utgångspunkter, undersöker utsatta gruppers begränsade och faktiska bosättningsmönster, men som regel spelar attributet "socialbidragstagare" en biroll och ofta står specifika bostadsområden eller kommundelar i fokus. Socialbidragstagarnas mellankommunala flyttmönster är - kort sagt - inte särskilt väl utforskat.

\section{Material och metod}

De data som analyseras i den här studien har hämtats från databasen PLACE, som har levererats till Kulturgeografiska institutionen i Uppsala av Statistiska Centralbyrån (SCB). Den innehåller avidentifierade registerdata på individnivå för hela den svenska befolkningen och omfattar årliga uppgifter avseende perioden 1990-2017. Förutom uppgifter om förekomst av socialbidrag finns allehanda socioekonomisk och demografisk information. Definitioner och operationaliseringar av olika kategorier följer SCB. Gängse bedömningar av relevans och kvalitet hos SCB:s data gäller alltså också här och inga data är förstås helt otadliga. Å andra sidan finns inget som tyder på brister som är systematiska på ett sätt som skulle kunna påverka resultaten $\mathrm{i}$ studien. Inte heller finns några bättre data att tillgå.

Det attribut som står i studiens fokus är förekomst av socialbidrag (oavsett summa 
eller tidsperiod). Det är ett mått som är individualiserat utifrån familj, det vill säga alla som lever i en familj där någon har socialbidrag räknas som socialbidragstagare. Fast kommunernas tvister handlar ju inte om dem som flyttar från bidrag till egen försörjning eller som får försörjningsproblem först efter flytten. Uppmärksamheten i studien begränsas därför till dem som är socialbidragstagare såväl före som efter flytten, det vill säga två år i rad. De övriga attribut som beaktas har befunnits vara av betydelse för flyttbenägenheten och används här främst som kontrollvariabler.

Att flytta operationaliseras här som byte av folkbokföringskommun från ett år till ett annat. I debattens kärnpunkt står å ena sidan kommuner med befolkningsminskning och lediga bostäder, som ibland beskrivs som "avstjälpningsplatser" för storstädernas bidragsberoende, å andra sidan storstadskommuner, som menar att de drar till sig socioekonomiskt svaga människor från hela landet i en sådan utsträckning att de tappar kontrollen över trångboddhet, segregation och social situation. Här operationaliseras den första typen som de kommuner vars befolkning minskade mellan åren 1990 och 2017, och den andra till de kommuner som, enligt SCB:s kategorisering, ingår i något av de tre storstadsområdena.

Om attributet "uppbär kontinuerligt socialbidrag" (dvs. två på varandra följande år) är vanligare bland de krympande kommunernas inflyttare från storstäder än bland deras inflyttare generellt, skulle det kunna indikera förekomst av "social export" från storstadskommuner. Om dessa socialbidragstagare är särskilt vanliga i den motsatta flyttströmmen skulle vi å andra sidan kunna tala i termer av "social import" till storstadskommunerna. Här kommer saken att undersökas deskriptivt, men eftersom flyttarna också bär med sig många fler attribut än "kontinuerlig förekomst" av socialbidrag och eftersom det sedan tidigare är känt att även dessa påverkar olika flyttbenägenheter, behöver vi försöka renodla effekten av kontinuerligt socialbidragstagande. I det syftet redovisas resultaten av några regressionsmodeller.

Modellerna behöver kunna hantera de typer av data som står till buds. Eftersom den beroende variabeln är binär (t.ex. flytta från storstadskommun till kommun med befolkningsminskning versus flytta från annan kommun till kommun med befolkningsminskning) och de oberoende variablerna nominala (t.ex. familjetyp) och ordinala (t.ex. ålder), behöver vi nyttja binär logistisk regression. Metoden innebär att de oberoende variablernas relationer till den beroende variabeln uttrycks som odds, som i sin tur logaritmeras. Därmed kan de bli föremål för regression trots att de inte är av typen intervallskala. Innan vi ger oss in på de flyttningar som är av huvudsakligt intresse här ska vi skaffa oss en bakgrundsbild av vilka de kontinuerliga socialbidragstagarna är och av deras allmänna flyttbenägenhet. 


\section{Bakgrund och flyttbenägenhet hos socialbidragstagare}

Rätten till socialbidrag (ekonomiskt bistånd) regleras i socialtjänstlagen. Av dess portalparagraf framgår att den syftar till att frigöra och utveckla människors egna resurser. Tanken är med andra ord inte att stödet ska vara permanent. Ändå uppbär en allt större del av socialbidragstagarna bistånd från år till år (jfr t.ex. Bergmark \& Bäckman 2007; Mood 2013). År 1991 hade 56 procent av socialbidragstagarna socialbidrag redan året före. År 2017 var motsvarande andel 67 procent.

Uttryckt som andel av befolkningen är förstås andelen kontinuerliga (dvs. två på varandra följande år) socialbidragstagare mindre. Den uppgick till 3,1 procent $\mathrm{i}$ början av 1990-talet. Under de därpå följande krisåren ökade andelen till 5,3 procent 1996-1997, för att sedan falla tillbaka till 2,3 procent i början av 2000-talet. Sedan mitten av 2000-talet har andelen pendlat kring 3 procent. Det framgår överst i tabell 1 , som också visar hur andelen kontinuerliga socialbidragstagare varierar i några olika subgrupper i befolkningen. Attributen "utländsk bakgrund", "ensamstående med barn" (jfr t.ex. Stranz \& Wiklund 2011; Gustafsson 2013) och "18-24 år" är särskilt exponerade, medan attributen "par utan barn", "svensk bakgrund", "postgymnasial utbildning" och "65-år" sällan kan knytas till kontinuerligt uppbärande av socialbidrag. Flera studier antyder att skillnaderna delvis förklaras av att socialarbetarnas bifallsbenägenhet varierar mellan olika klientgrupper (se t.ex. Stranz, Karlsson \& Wiklund 2017; Hussénius 2019), men det spelar mindre roll för syftet med denna studie. 
Tabell 1. Andel kontinuerliga (två år i följd) socialbidragstagare i Sveriges vuxna befolkning vid några tidpunkter, totalt och fördelat på subgrupper.

\begin{tabular}{|c|c|c|c|c|c|}
\hline $\begin{array}{l}\text { Andel kontinuerliga } \\
\text { socialbidragstagare }\end{array}$ & & $\begin{array}{r}1990-91 \\
\%\end{array}$ & $\begin{array}{r}1996-97 \\
\%\end{array}$ & $\begin{array}{r}2001-2002 \\
\%\end{array}$ & $\begin{array}{r}2016-2017 \\
\%\end{array}$ \\
\hline Totalt & $18+$ & 3,1 & 5,3 & 2,3 & 2,7 \\
\hline \multicolumn{6}{|l|}{ Utbildning } \\
\hline & ej postgy. & 4,2 & 6,4 & 2,7 & 3,6 \\
\hline & postgy. & 1,5 & 3,0 & 1,1 & 1,2 \\
\hline \multicolumn{6}{|l|}{ Familj } \\
\hline & ensamstående & 3,5 & 5,5 & 3,1 & 2,9 \\
\hline & par utan barn & 0,6 & 1,2 & 0,6 & 1,0 \\
\hline & ensamst. m. barn & 10,3 & 14,7 & 6,9 & 7,4 \\
\hline & par med barn & 2,8 & 5,7 & 1,7 & 2,5 \\
\hline \multicolumn{6}{|l|}{ Bakgrund } \\
\hline & svensk & 2,8 & 3,9 & 1,4 & 1,1 \\
\hline & utländsk & 10,8 & 19,4 & 8,9 & 8,5 \\
\hline \multicolumn{6}{|l|}{ Kön } \\
\hline & män & 3,2 & 5,3 & 2,3 & 2,8 \\
\hline & kvinnor & 3,0 & 5,3 & 2,4 & 2,7 \\
\hline \multicolumn{6}{|l|}{ Ålder } \\
\hline & $18-24$ & 5,1 & 11,8 & 4,7 & 4,9 \\
\hline & $25-44$ & 4,8 & 7,5 & 3,2 & 3,1 \\
\hline & $45-64$ & 2,0 & 3,5 & 1,8 & 2,7 \\
\hline & $65+$ & 0,8 & 1,1 & 0,8 & 1,4 \\
\hline
\end{tabular}

Källa: Databasen PLACE, Uppsala universitet. Alla kategoriseringar följer SCB.

Figur 1 illustrerar hur den mellankommunala flyttbenägenheten har utvecklats mellan åren 1991 och 2017. I befolkningen som helhet har flyttbenägenheten ökat från strax under, till strax över fyra procent. Samtidigt har den minskat bland socialbidragstagarna som, detta till trots, fortfarande år 2017 har en högre flyttbenägenhet än genomsnittligt.

Socialbidragstagandet är vanligare $\mathrm{i}$ en del subgrupper än $\mathrm{i}$ andra (tabell 1). Följaktligen kommer andelen socialbidragstagare att påverkas om totalbefolkningens fördelning på subgrupperna förändras över tid. Så bidrar till exempel en ökande andel invånare med utländsk bakgrund i befolkningen till att andelen socialbidragstagare ökar, medan den ökande andelen postgymnasialt utbildade har motsatt effekt.

Genom att applicera den ålders- och bakgrundsstruktur som 1991 års kontinuer- 
liga socialbidragstagare uppvisar på de ålders- och födelsebakgrundsspecifika flyttbenägenheterna från 2017 kan man räkna ut effekten av förändringar i ålders- och bakgrundssammansättning. Med oförändrad sammansättning av de attribut som redovisas i tabell 1 skulle flyttbenägenheten bland kontinuerliga socialbidragstagare ha minskat från 8,8 procent år 1991 till 7,2 procent år 2017. I verkligheten föll den ända till 5,6 procent (figur 1). Drygt hälften av den minskande flyttbenägenheten hänför sig alltså till strukturella förändringar i gruppens sammansättning. Om vi har lyckats ta hänsyn till den relevanta sammansättningen av bakgrund skulle alltså knappt hälften av förändringen bero på beteendeförändringar (på tvärs mot den generella utvecklingen). Möjligen kan beteendeförändringarna tolkas som ett uttryck för minskande möjligheter att flytta från en kommun till en annan i takt med en hårdnande bostadsmarknad och ett tuffare biståndsklimat.

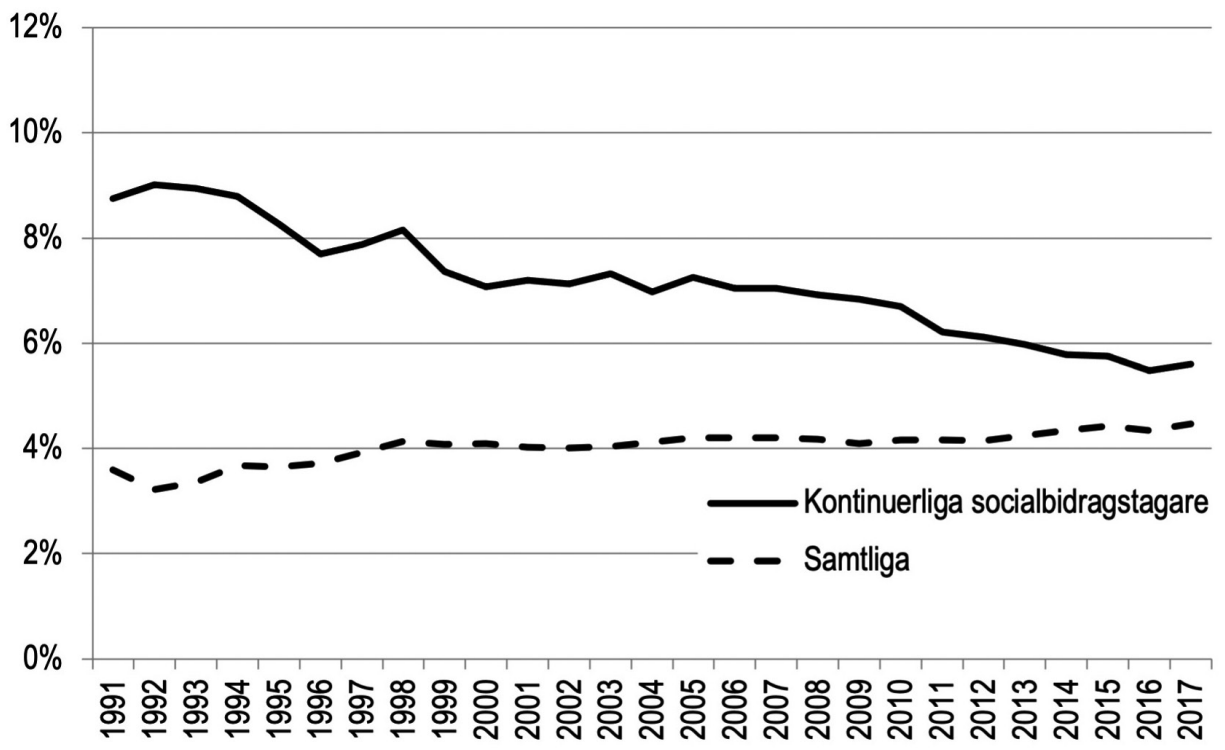

Figur 1. Mellankommunal flyttfrekvens 1991-2017 bland totalbefolkning och bland invånare som uppbar socialbidrag två år i följd (såväl före som efter flytten). Källa: Databasen PLACE, Uppsala universitet. 
Sammanfattningsvis kan vi som bakgrund konstatera att socialbidragstagandet $\mathrm{i}$ allt mindre grad är tillfälligt och att den andel av befolkningen som uppbär socialbidrag flera år i följd, efter en ökning under 1990-talets krisår, totalt sett har minskat sedan 1990-talets början. För studiens centrala tema kan vi konstatera att de kontinuerliga socialbidragstagarnas mellankommunala flyttbenägenhet fortfarande är högre än i befolkningen generellt, men att den, i motsats till den allmänna utvecklingen, minskar. Minskningen hänför sig delvis till att gruppen har en förändrad demografisk sammansättning, men också beteendeförändringar - som i sin tur skulle kunna hänföra sig till förändrade möjligheter - verkar spela en roll.

\section{Socialbidragstagarnas flytt mellan storstad och avfolkningsbygd}

Figur 2 visar hur flyttströmmarna har rört sig 1991-2017 mellan storstadskommuner och kommuner med befolkningsminskning. De tjocka linjerna representerar kontinuerliga socialbidragstagares flyttningar och de tunna hela befolkningen. Streckade linjer representerar flyttning från minskande kommuner till storstadsregioner och heldragna motsatt flyttriktning.

Låt oss först konstatera att de båda tjocka linjerna ligger över sina tunna motsvarigheter. Det innebär att de kontinuerliga socialbidragstagarna är överrepresenterade i flyttutbytet mellan storstads- och minskande kommuner, oavsett flyttriktning. Det stämmer överens med budskapet från figur 1. Vidare framgår att de streckade linjerna är mer åtskilda än de heldragna. Alltså är socialbidragstagarnas överrepresentation större bland flyttare från minskande kommuner till storstadskommuner, än i motsatt flyttström, under merparten av perioden 1990-2017.

Vi kan också notera att, frånsett några år i början av 2000-talet och år 2017, har fler kontinuerliga socialbidragstagare flyttat från minskande kommuner till storstäder än $\mathrm{i}$ motsatt riktning. Den i pressen omskrivna "sociala exporten" från storstäderna har med andra ord - åtminstone i nettotermer - varit undantag snarare än regel. Undantaget i början av 2000-talet var emellertid del i en generell kontraurban flyttvåg (jämför de båda tunna linjerna), medan läget år 2017 inte har någon sådan motsvarighet.

Till sist kan påminnas om att den stora nedgång av de kontinuerliga socialbidragstagarnas flyttning från kommuner med befolkningsminskning till storstadskommuner, som avtecknar sig i undersökningsperiodens inledning, kan förstås som en effekt av "hela-Sverige-strategins" "avskaffande i början av 1990-talet.

1 Hela-Sverige-strategin var en politik som tillämpades åren 1987-1991 (i någon mån ända till 1994) med syfte att minska invandringens geografiska koncentration till de största städerna. Vissa förmåner (t.ex. tillgång till bostad och introduktionsprogram) kopplades till en anvisad kommun under de invandrades första 18 månader i Sverige. 


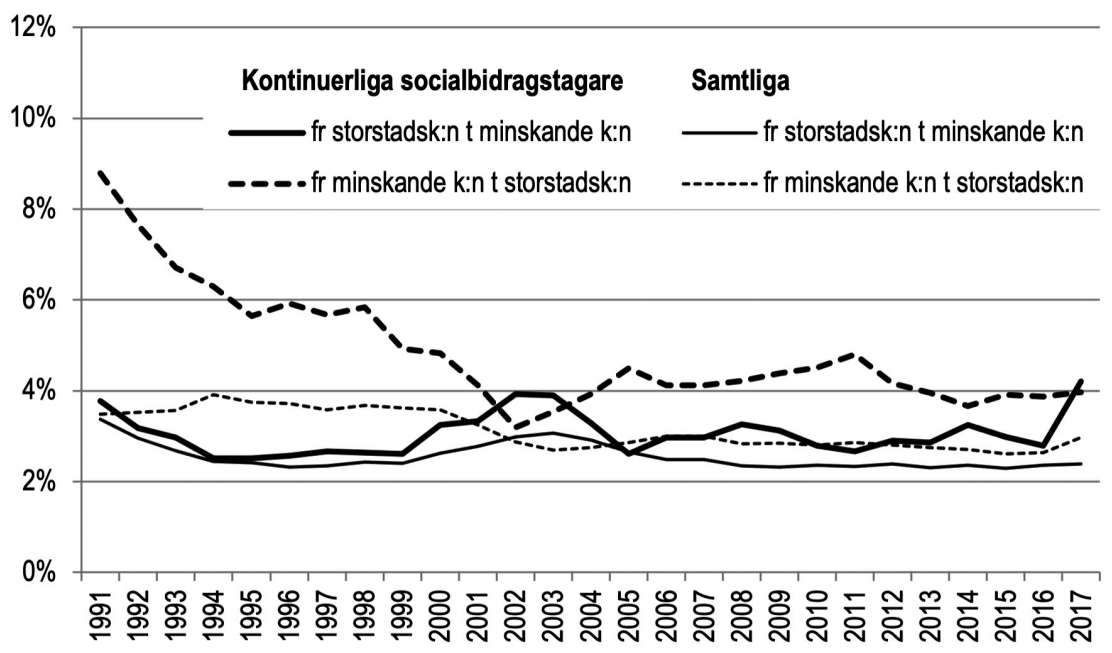

Figur 2. Flyttrörelser mellan storstadskommuner och kommuner med befolkningsminskning som andel av all mellankommunal flytt, 1991-2017, samtliga flyttare och flyttare som uppbar socialbidrag två år i följd (såväl före som efter flytten). Källa: Databasen PLACE, Uppsala universitet.

Tabell 1 visade att invånare med utländsk bakgrund är överrepresenterade bland de kontinuerliga socialbidragstagarna; mot slutet av perioden hade över 70 procent av dem utländsk bakgrund. Som framgått är "invånare med utländsk bakgrund" en grupp som också har en särställning i pressdebatten. Tabell 2 redovisar hur många kontinuerliga socialbidragstagare med utländsk (och svensk) bakgrund som har flyttat mellan storstadskommuner och minskande kommuner mellan åren 2000 och 2017.2

Tabell 2. Totala antal flyttare (18 år) 2000-2017 mellan storstadskommuner och minskande kommuner 2000-2017 med/utan socialbidrag två år i följd (såväl före som efter flytten) fördelade på svensk/ utländsk bakgrund och totalt

\begin{tabular}{lrrrr} 
& \multicolumn{3}{l}{$\begin{array}{l}\text { Från storstads- till mins- } \\
\text { kande kommuner }\end{array}$} & \multicolumn{2}{l}{$\begin{array}{l}\text { Från minskande till storstads- } \\
\text { kommuner }\end{array}$} \\
& Kont. soc.-bidr. & Övriga & Kont. soc.-bidr. & Övriga \\
\hline Svensk bakgrund & 4620 & 104518 & 4501 & 117342 \\
Utländsk bakgrund & 5075 & 28710 & 9228 & 40792 \\
därav nyanlända (inom tre år) & 1404 & 4566 & 2804 & 9953 \\
Totalt & 9695 & 133228 & 13729 & 158134 \\
\hline
\end{tabular}

Källa: Databasen PLACE, Uppsala universitet.

2 Skälet till att utelämna 1990-talet i tabellredovisningen är att undvika att 2000-talets utveckling drunknar i de stora, urbant orienterade flyttningarna i kölvattnet av hela-Sverige-strategins avveckling. 
En jämförelse av de två kolumner som redovisar "övriga" flyttare visar vad som är närmast definitionsmässigt givet här, att nettoeffekten av flyttutbytet är till storstadskommunernas favör. Denna befolkningsomfördelning är särskilt tydlig bland flyttare med utländsk bakgrund. Bland individer med svensk bakgrund är flyttutbytet av kontinuerliga socialbidragstagare i stort sett balanserat, medan det har en tydlig slagsida (till storstadskommunernas favör) bland individer med utländsk bakgrund i allmänhet och bland nyanlända i synnerhet. Slagsidan är större bland kontinuerliga socialbidragstagare med utländsk bakgrund än bland övriga med utländskt påbrå.

Bland nyanlända invandrare finns dock en kraftig uppgång i flyttningen från storstäder till avfolkningskommuner bland kontinuerliga socialbidragstagare under det sist studerade året, 2017. (Det är den som slår igenom i figur 2.) Då flyttade 271 nyanlända med kontinuerliga socialbidrag från en storstadskommun till en kommun med befolkningsminskning (att jämföra med ett genomsnitt på 83 under dittillsvarande 2000-talet). Möjligen är det upprinnelsen till diskussionen om social export i slutet av 2010-talet. Möjligen indikerar uppgången år 2017 också ett nytt läge, där nettoflyttningen mellan storstads- och minskande kommuner har bytt riktning permanent, men i nuläget saknas data att undersöka det.

$\mathrm{Nu}$ finns det fler attribut än utländsk bakgrund som kan samvariera med socialbidragstagarnas flyttning mellan vissa typer av kommuner. Med syfte att beakta dem och renodla effekten av attributet "kontinuerlig socialbidragstagare" har binära logistiska regressioner genomförts. Resultaten presenteras, som brukligt, i form av oddskvoter. Signifikanta värden över 1,0 innebär att ifrågavarande attribut, jämfört med referensattributet, indikerar högre sannolikhet för den typ av flytt som mäts. Signifikanta värden under 1,0 indikerar en mindre sannolikhet.

Inflyttare från storstadskommuner till minskande kommuner avviker i vissa avseenden från andra inflyttare till minskande kommuner. Hur avvikelserna såg ut senast kända år, samt som jämförelse tio år tidigare, framgår av modell 2 respektive 1 . I flertalet avseenden är bilden oförändrad över tid; att vara äldre, välutbildad, leva i en familjekonstellation och ha utländskt påbrå är attribut som ökar sannolikheten att en inflyttare till en kommun med befolkningsminskning har sin härkomst i en storstadskommun. Attributet "kontinuerlig socialbidragstagare" minskade den sannolikheten år 2006-2007. Härvidlag hade emellertid läget förändrats tio år senare; bland inflyttare till minskande kommuner 2016-2017 ökade attributet "kontinuerlig socialbidragstagare" sannolikheten för storstadshärkomst. Å andra sidan är detta attribut det av alla som avviker minst från oddskvoten 1 (det värde som indikerar att ingen skillnad finns mellan storstads- och annan härkomst). Resultatet kan knappast tas som intäkt för påståendet om "social export", men hade läget från 2006-2007 kvarstått hade resultatet talat för att avfärda det. 
Tabell 3. Resultat av binära logistiska regressionsmodeller av flyttare till/från storstads- och krympande kommuner 2006-07 och 2016-17, oddskvoter

Flyttare från storstads-

Ref: Antal inflyttare till minskande kommuner

Kön (ref = man)

Kvinna

Ålder $(\mathrm{ref}=35-64)$

$0-17$

$18-24$

25-34

65

Utl. bakgrund (ref $=$ nej)

Ja

Kontinuerlig soc.-bidrag (ref $=$ nej)

Ja

Familj (ref = ensamst. utan barn)

Par utan barn

Ensamst. med barn

Par med barn

Postgy. Utb. (ref = nej)

Ja

Konstant

$n$

Nagelkerke $\mathrm{R}^{2}$
${ }^{*} p<0,05 ;{ }^{* *} p<0,01$.

Källa: Databasen PLACE, Uppsala universitet.
Modell 1
1,03

$$
0,97
$$

Flyttare från storstadstill minskande kommuner

16-17
$0,55^{* *}$

$0,70^{* *}$

$0,93^{* *}$

$1,08^{* *}$

$1,33^{* *}$

$0,89^{*}$

$1,42^{* *}$

$1,09^{* *}$

$1,23^{* *}$

$1,38^{* *}$

$1,55^{* *}$

\section{Modell 2}

$0,61^{* *}$

$0,69 * *$

$0,83^{* *}$

$1,22^{* *}$

$1,18^{* *}$

$1,14^{* *}$

$1,17^{* *}$

$1,14^{* *}$

$1,15^{* *}$

$0,18^{* *}$

$0,19^{* *}$

42875

49324

0,023 
Flyttare från minskande till storstadskommuner storstadskommuner

Kön (ref = man)

Kvinna

Ålder (ref = 35 - 64)

0-17

18-24

25-34

65

Utl. bakgrund (ref $=$ nej)

Ja

Kontinuerlig soc.-bidrag (ref $=$ nej)

Ja

Familj (ref = ensamst. utan barn)

Par utan barn

Ensamst. med barn

Par med barn

Postgy. Utb. (ref = nej)

Ja

Konstant

n

Nagelkerke $\mathrm{R}^{2}$
Modell 3 06-07

1,01

\section{Modell 4}

Flyttare från minskande till storstadskommuner 16-17

$0,93^{* *}$

1,18

$1,37^{* *}$

$1,55^{* *}$

$1,37^{* *}$

$0,90^{* *}$

$0,98^{* *}$

$1,40^{* *}$

$1,80^{* *}$

$0,70^{* *}$

$1,55^{* *}$

$2,01^{* *}$

$1,55^{*}$

$0,72^{* *}$

$0,74^{* *}$

$0,71^{* *}$

$0,68^{* *}$

$0,50^{* *}$

$0,72^{* *}$

$0,67^{* *}$

$0,62^{* *}$

$0,08^{* *}$

$0,07^{* *}$

142838

172460

0,039

0,066 
Modell 3 och 4 visar hur inflyttare från minskande kommuner till storstadskommuner avviker från storstadsinflyttarna i allmänhet, åren 2006-2007 respektive 20162017. Också härvidlag är det mesta sig likt över tid; attributen att vara under 25 eller minst 65 år gammal, ensamstående och lågutbildad ökar sannolikheten för att en storstadsinflyttare har sin härkomst i en minskande kommun. Dit hör också kontinuerlig förekomst av socialbidrag. Den enda förändringen gäller attributet "utländsk bakgrund", som minskade sannolikheten att en storstadsinflyttare hade sin härkomst i en kommun med minskande befolkning 2006-2007, men som ökade den tio år senare, 2016-2017.

Sammanfattningsvis visar regressionsanalyserna att attributet "kontinuerlig socialbidragstagare" ökar sannolikheten för storstadshärkomst bland 2017 års inflyttare till kommuner med befolkningsminskning även när betydelsen av en rad andra attribut kontrolleras bort. Detsamma gäller emellertid också flyttning i motsatt riktning, där effekten är starkare. Kort sagt förändrar inte regressionsanalysen den lägesbild från sent 2010-tal som den deskriptiva genomgången gav vid handen.

\section{Hur länge bor inflyttarna kvar?}

Det är väl känt att sannolikheten att flytta minskar med den tid man har varit bosatt på en plats (t.ex. Fischer \& Malmberg 2001). Aktuella erfarenheter av flyttning ökar med andra ord sannolikheten för en ytterligare flytt. Långt ifrån alla som flyttar någonstans blir kvar. För att undersöka hur det är med den saken bland kontinuerliga socialbidragstagare, har vi följt flyttare mellan storstadskommuner och kommuner med befolkningsminskning från och med år 2012 och framåt. Eftersom tillgängliga data sträcker sig till och med år 2017 kan vi då följa kvarboendet upp till fem år efter flytten. Resultatet illustreras av figur 3 och 4. 


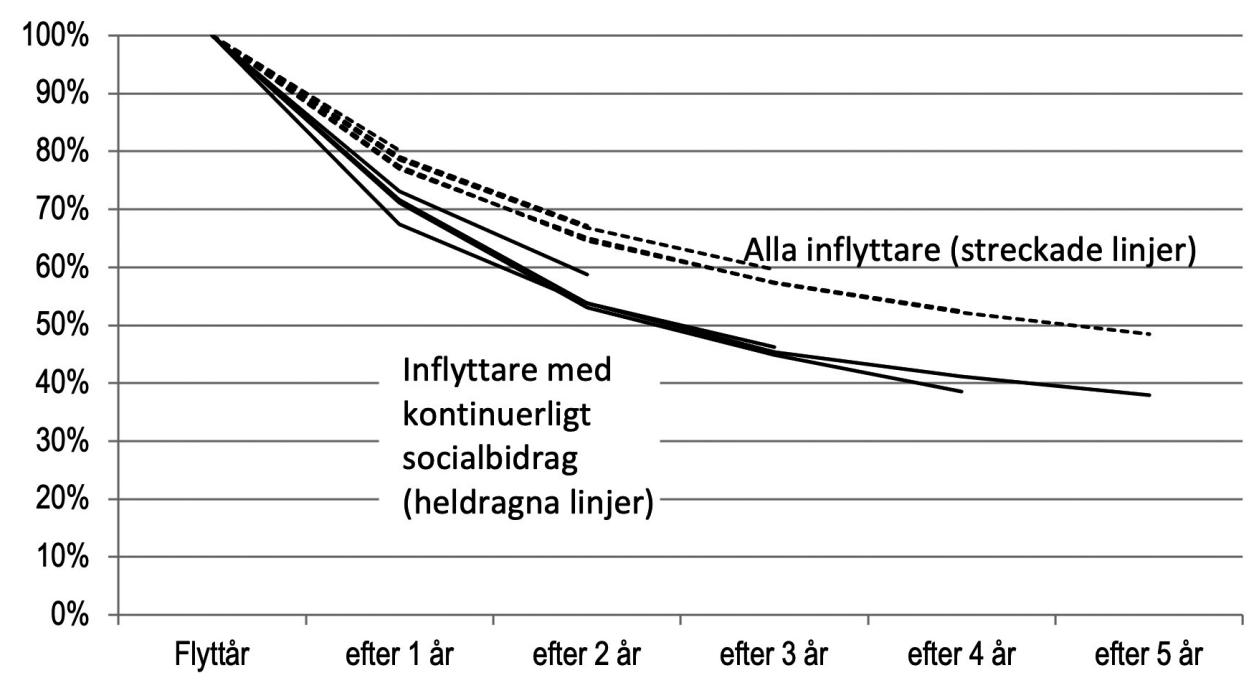

Figur 3. Kvarboende bland inflyttare (2012-2017) från storstadskommuner till kommuner med befolkningsminskning 1990-2017. Källa: Databasen PLACE, Uppsala universitet.

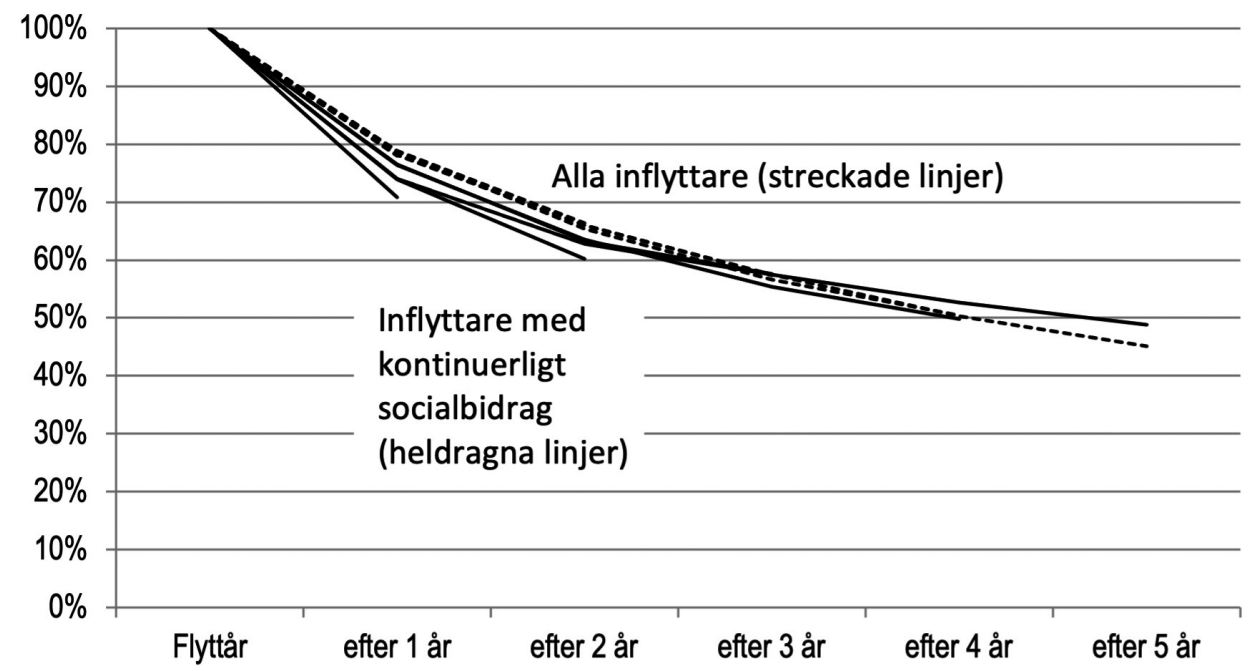

Figur 4. Kvarboende bland inflyttare (2012-2017) från kommuner med befolkningsminskning 19902017, till storstadskommuner. Källa: Databasen PLACE, Uppsala universitet. 
Av människor med kontinuerliga socialbidrag som inflyttar till krympande kommuner, flyttar cirka 30 procent vidare redan inom ett år. Efter tre år bor mindre än hälften kvar. Därvidlag avviker de från andra inflyttare till samma slags kommuner, som har en större benägenhet att bo kvar. De avviker också från storstadskommunernas inflyttare med kontinuerliga socialbidrag, som blir kvar i högre grad, i stort sett i lika hög grad som andra inflyttare till storstadskommuner.

Därmed kan vi konstatera att de kontinuerliga socialbidragstagare som flyttar från storstadskommuner till kommuner med befolkningsminskning bor kvar i mindre utsträckning än både andra inflyttare till dessa (krympande) kommuner och flyttare i motsatt riktning (oavsett om de uppbär socialbidrag eller inte). Kontinuerliga socialbidragstagare som flyttar från kommuner med minskande befolkning till storstadskommuner bor däremot kvar i nästan samma utsträckning som andra flyttare.

\section{Sammanfattande diskussion}

Mot bakgrund av medieuppmärksamhet och samhällsdebatter där många kommuner menar att de i oskälig utsträckning får ta emot inflyttande hushåll med behov av bistånd har här undersökts hur de faktiska flyttströmmarna mellan storstads- och befolkningsminskande kommuner ser ut, med särskilt fokus på (majoriteten) socialbidragstagare som uppbär bistånd under flera år i följd. Vi har kunnat konstatera att dessa kontinuerliga socialbidragare generellt sett är mer flyttbenägna än genomsnittligt och att det också gäller det specifika flyttutbytet mellan storstadskommuner och minskande kommuner, fast gruppens flyttbenägenhet faller över tid, samtidigt som andra gruppers ökar (figur 1 och 2). Data ger också vid handen att nettoomfördelningen av kontinuerliga socialbidragstagare, frånsett några enstaka år, har gått från minskande kommuner till storstadskommuner (figur 2). Fast det kan noteras att det senast undersökta året, 2017, som ligger i kölvattnet efter en stor invandringsvåg, tillhör de enstaka undantagen (figur 2). Av några undersökta attribut visar sig "utländsk bakgrund" vara mest överrepresenterat bland kontinuerliga socialbidragstagare (tabell 1) och det är den gruppen som huvudsakligen svarar för nyss nämnda geografiska nettoomfördelning. Den mellankommunala nettoomfördelningen bland kontinuerliga socialbidragstagare med svensk bakgrund är däremot obetydlig (tabell 2).

Med en binär logistisk regressionsanalys har undersökts vilka attribut som gör det mer sannolikt att en inflyttare till en minskande kommun har sin härkomst i storstäder och vice versa. Detta har undersökts det sista studerade året, 2017, strax efter en stor invandringsvåg, och som jämförelse tio år tidigare, 2007. Attributet kontinuerlig socialbidragstagare visar sig markant öka sannolikheten att en inflyttare till en storstadskommun har sin härkomst i en minskande kommun, men bara måttligt och bara vid det senare tillfället, att en inflyttare till en minskande kommun har sin härkomst i 
en storstadskommun (tabell 3). Avslutningsvis kunde vi konstatera att kontinuerliga socialbidragstagare som flyttar från en storstadskommun till en minskande kommun har ett lägre kvarboende än andra människor som gör samma flytt, något som inte gäller socialbidragstagare som flyttar i motsatt riktning (figur 3 och 4).

Utifrån de data som har analyserats här antyder flyttströmmar alltså huvudsakligen en "social import" till storstadskommuner, snarare än en export därifrån. Effekten av fenomenet skärps dessutom om man tar hänsyn till hur de flyttande socialbidragstagarnas kvarboendegrader skiljer sig mellan de två kommungrupperna. Fast man kan förstås spekulera i om den avvikelse från det förhållandet som plötsligt inträffar det sista undersökta året, 2017, är början på en ny permanent ordning med motsatt nettoflyttriktning. Att pressuppmärksamheten har intensifierats mot slutet av 2010-talet skulle kunna tala för det. De kontinuerliga socialbidragstagarnas nettoflyttriktning (från minskande kommuner till storstadskommuner) står inte heller nödvändigtvis i motsättning till förekomst av social dumpning och hyresvärdar som drar nytta av den. Om inte sådana beteenden är av tillräcklig omfattning skulle de helt enkelt kunna ha "drunknat" $\mathrm{i}$ socialbidragstagarnas övriga flyttningar. Fast att på något annat övertygande vis belägga eventuella otillbörliga avsikter hos fastighetsägare eller storstadskommuner är nog svårt (jfr Statskontoret 2020 samt Delby 2020), och ligger i vilket fall utanför den här studiens anspråk.

De mellankommunala dispyter som har uppmärksammats här kan alltså följas i pressinlägg sedan decennier och möjligen är de den senaste delen i en följetong som började med "sockenkriget" för mer än 200 år sedan. I ett läge där avsikterna bakom kommuners och fastighetsägares handlingar är oklara och flyttströmmarnas budskap inte är helt entydigt, hyser jag inga illusioner om att de mellankommunala motsättningarna är på väg att upphöra. I grund och botten är det också tvetydigt om dispyten handlar om regler (t.ex. justeringen av EBO-lagen eller att på något vis hindra dumpningsbeteenden och "oseriösa" fastighetsägare) eller om fördelningen av ekonomiska bördor (kostnader för t.ex. socialbidrag). Det är nämligen inte säkert att regeljusteringar skulle påverka flyttströmmarna av bidragstagare.

Ett alternativt sätt att bilägga de återkommande mellankommunala dispyterna skulle kunna innebära att kostnaderna för socialbidrag på något vis tas ut nationellt. Det skulle visserligen inte nödvändigtvis hindra uppkomsten av geografiska koncentrationer av sociala problem, men skulle i högre grad göra uppgiften att hantera dem gemensam och minska kommunernas incitament att dumpa någon på andra sidan kommungränsen. Därmed skulle också bidragstagarnas situation bli mindre utsatt.

Av litteraturgenomgången framgick att socialbidragstagarnas flyttmönster hittills inte har varit särskilt uppmärksammat, utan snarare förekommit i förbigående i flera litteraturer. De resultat som presenterats här bygger på en grovt tillyxad operationalisering av socialbidragstagare och en geografisk indelning med nyanserings- 
potential, men ligger väl i linje med tidigare slutsatser om att geografiskt varierande välfärd inte har stora effekter på flyttmönster och med segregationsforskningens rön om att utsatta grupper tenderar att hamna på samma platser. För vidare forskning inom området skulle betydelsen av förfinade operationaliseringar av socialbidragstagare med fördel kunna undersökas, liksom eventuella skillnader mellan kommuner i de två grupperna.

\section{Referenser}

Alm, J. \& Enami, A. (2017) Do government subsidies to low-income individuals affect interstate migration? Evidence from the Massachusetts Health Care Reform. Regional Science and Urban Economics, 66: 119-131.

Amcoff, J., Niedomysl, T. \& Östh, J. (2011a) Vart tar invandrarna vägen? Vidareflyttning under 00-talet bland nyanlända flykting-, arbets- och äktenskapsinvandrare. Demografisk rapport 2011:4. Stockholms läns landsting.

Amcoff, J. Niedomysl, T. \& Östh, J. (2011b) "Pensionspuckeln": 55+-flyttningar till och från Stockholmsregionen. Demografisk rapport 2011:2. Stockholms läns landsting.

Andersson, R. \& Bråmå, Å. (2004) Selective migration in Swedish distressed neighbourhoods. can area-based urban policies counteract segregation processes? Housing Studies, 19(4): 517-539.

Baeten, G. \& Listerborn, C. (2015) Renewing urban renewal in Landskrona, Sweden. Pursuing displacement through housing Policies. Geografiska Annaler B, 97(3): 249-261.

Baeten, G., Westin, S., Pull, E. \& Molina, I. (2017) Pressure and violence. Housing renovation and displacement in Sweden. Environment and Planning A, 49(3): 631-651.

Beatty, C. \& Fothergill, S. (2004) Economic change and the labour market in Britain's seaside towns. Regional Studies, 38(5): 461-480.

Bergmark, Å. \& Bäckman, O. (2007) Socialbidragstagandets dynamik. Varaktighet och utträden från socialbidragstagande under 2000-talet. Socialvetenskaplig tidskrift, 14(2-3): 134-152.

Björkqvist, K. (1996) Bostadsbolag föredrar tomma lägenheter framför bidragstagare. Svenska Dagbladet, 1996-08-23.

Boffy-Ramirez, E. (2013). Minimum wages, earnings, and migration. IZA Journal of Migration, 2: 17.

Borglin, ̊̊. (2019) Bromölla befarar "social dumpning". Kristianstadsbladet, 2019-11-19.

Bråmå, Å. \& Andersson, R. (2010) Who leaves rental housing? Examining possible explanations for ethnic housing segmentation in Uppsala, Sweden. Journal of Housing and the Built Environment, 25:335-352.

Dahlqvist, M. (2019) Skriftlig fråga till statsråd 2018/19:702. Export av socialt utsatta människor.

De Giorgi, G. \& Pellizzari, M. (2009) Welfare migration in Europe. Labour Economics, 16: 353-363.

Delby, J. (2020) Social dumpning. Miss i rapport från Statskontoret. Dagens Samhälle, (40): 14.

Edmark, K. (2007) Påverkar olika hårda krav på aktivering av socialbidragstagare var man väljer att bo? IFAU, Rapport 2007:26.

Edmark, K. (2009) Migration effects on welfare benefit reform. Scandinavian Journal of Economics, $111(3): 511-526$.

Ekorre, P. (2020) Gävle är utsatt för social dumpning. Det måste vi sätta stopp för. Gefle Dagblad, 2020-10-01. 
Eriksson, A. K. (2020) Minister agerar mot social dumpning. TT Nyhetsbyrån, 2020-01-14.

Femenías, P., Jonsdotter, L., Knutsson, A., Forsemalm, J. \& Karlsson, R. (2019) Flytt i samband med renovering. Preliminära resultat från en pilotstudie. Göteborg: Institutionen för arkitektur och samhällsbyggnadsteknik, Avdelningen för Byggnadsdesign, Chalmers tekniska högskola.

Fisher P. A. \& Malmberg G. (2001) Settled people don't move. On life course and (im-)mobility in Sweden. International Journal of Population Geography, 7(5):357-371.

Fiva, J. H. (2009) Does welfare policy affect residential choices? An empirical investigation accounting for policy endogeneity. Journal of Public Economics, 93: 529-540.

Fritze, G. (2015) Vellinge sysslar med social dumpning. SVT, 2015-11-05.

Gard, A. \& Lundgren, E. (2021) Investera i bostäder och människor för ökad jämlikhet. Gefle Dagblad, 2021-01-27.

Godner, B. (2016) EBO - raka spåret till segregation. SVT Opinion, 2016-02-10.

Godner, B. (2018) Yttrande över betänkande från Mottagandeutredningen (SOU 2018:22). Södertälje kommun.

Goodman, L. (2017) The effect of the affordable care act Medicaid expansion on migration. Journal of Policy Analysis and Management, 36(1): 21 1-238.

Gramlich, E. \& Laren, D. (1984) Migration and income redistribution responsibilities. The Journal of Human Resources, 19(4): 489-511.

Grander, M. (2017) New public housing. A selective model disguised as universal? Implications of the market adaption of Swedish public housing. International Journal of Housing Policy, 17(3): 335-352.

Grander, M. (2018) Off the beaten track? Selectivity, discretion and path-shaping in Swedish public housing. Housing, Theory and Society, 36(4): 385-400.

Gustafsson, A. (2020) Allt större problem med social dumpning i Heby. Upsala Nya Tidning, 2020-11-27.

Gustafsson, B. A. (2013) Social assistance among immigrants and natives in Sweden. International Journal of Manpower, 34(2): 126-141.

Hedman, L., van Ham, M. \& Manley, D. (2011) Neighbourhood choice and neighbourhood reproduction. Environment and Planning A, 43(6): 1381-1399.

Helsingborgs Dagblad (1998) Dyrt lockbete för flyktingar. Kommunen trött på "oseriösa" fastighetsägare. Helsingborgs Dagblad, 1998-11-06.

Hussénius, K. (2019) Intersectional patterns of social assistance eligibility in Sweden. Nordic Social Work Research. Stockholm: Stockholms universitet, Samhällsvetenskapliga fakulteten, Institutionen för socialt arbete - Socialhögskolan.

Höen Bustos, E. (2020) Var ska "socialfallen" bo om inte i allmännyttan? Avesta Tidning, 2020-02-21.

Jofre-Monseny, J. (2014) The effects of unemployment protection on migration in lagging regions. Journal of Urban Economics, 83: 73-86.

Johansson, C. (2017) Vinner mot kommun. Har rätt till bidrag trots flytt till ort med hög arbetslöshet. Dagens Juridik, 2017-05-23.

Johansson, E-L. (2019) Ewa-Leena Johansson. Rika kommuner skyfflar över ansvaret för nyanlända till andra. Nerikes Allehanda, 2019-09-02.

Knutson, M. (2019) Kostnaderna dumpas i de fattiga kommunerna. Expressen, 2019-07-21.

Löfstrand, J. (2021) Rika kommuner sviker och dumpar människor. Aftonbladet, 2021-02-01 samt replik 2021-02-07 och slutreplik 2021-02-09.

McKinnish, T. (2005) Importing the poor. Welfare magnetism and cross-border welfare migration. The Journal of Human Resources, 40(1): 57-76. 


\section{Socialvetenskaplig tidskrift 2021:1}

Mood, C. (2013) Social assistance dynamics in Sweden. Duration dependence and heterogeneity. Social Science Research, 42: 120-139.

Olausson, P. (2016) Rotehjonet och döden. Fattigdomens betydelse för socknarnas formering. I: Den svenska socknen. Riksarkivets årsbok 2016, 81-98.

Olsson, L. (1999) Kommuntvister drabbar utsatta. Svenska Dagbladet, 1999-01-09.

Oscarsson, M. (2021) Interpellation till statsråd 2021:230. Kommuners medverkan till ofrivillig bosätttning $i$ en annan kommun.

Polanska, D. V. \& Richard, Å. (2018) Bortträngning pågår. Renovering som kulturellt trauma. Sociologisk forskning, 55(2-3): 415-439.

Regeringen (2020) Uppdrag att kartlägga aktiv medverkan till bosättning i annan kommun. Regeringsbeslut Fi2019/03535K, Fi2019/03928K, Fi 2020/00543K.

Schwarz, A. L. \& Sommers, B. D. (2014) Moving for Medicaid? Recent eligibility expansions did not induce migration from other states. Health Affaires, 33(1): 88-94.

SFS (2019) Lag om ändring $i$ lagen (1994:137) om mottagande av asylsökande m.fl. Justitiedepartementet. SFS 2019:1204.

Sjöstedt, S. (2019) Det är här rika städer dumpar sina oönskade. Tidningen Ångermanland, 2019-09-30.

Statskontoret (2020) Aktiv medverkan till bosättning $i$ annan kommun. En kartläggning. Statskontoret 2020:19.

Stjernfeldt-Jammeh, K. (2018) Välkommen till en packad trea i Malmö, Kristersson. Svenska Dagbladet, 2018-02-24.

Stranz, H., Karlsson, P. \& Wiklund, S. (2017) Det yttersta skyddsnätet. Om beslutsfattande i socialbidragsärenden i Sverige. European Journal of Social Work, 20(5): 711-723.

Stranz, H. \& Wiklund, S. (2011) I välfärdssamhällets mnarginal. Om socialbidragstagande bland ensamstående mödrar av svensk och utländsk härkomst. Socialvetenskaplig tidskrift, 18(1): 42-62.

Swedin, D. (2019) Stockholm dumpar hemlösa på landet. Social export till Hagfors, Filipstad \& Ljusnarsberg. Aftonbladet, 2019-07-22.

Wallin, T. (2019) Bengtsfors i blickpunkten. Dalslänningen, 2019-09-17.

Ward, K. J. (2015) Geographies if exclusion. Seaside towns and houses in multiple occupancy. Journal of Rural Studies, 37: 96-107.

Westerdahl, S. (2020) Fastighetsutveckling. Pågående förändringsprocesser på bostadsmarknaden. I: M. Gerell, P-O. Hallin, K. Nilvall \& S. Westerdahl (red.) Att vända utvecklingen. Från utsatta områden till trygghet och delaktighet. MAPIUS 26, 59-67.

Åslund, O. (2005) Now and forever? Initial and subsequent location choices of immigrants. Regional Science \& Urban Economics, 35: 141-165. 